\title{
Quantitative Analyses of Cells using Photoshop after the H\&E Staining of the Synovia of Osteoarthritis and Rheumatoid Arthritis Patients
}

\author{
Jin-Ah Park and Keun-Cheol Kim*
}

Department of Biological Sciences, College of Natural Sciences, Kangwon National University, Chuncheon 200-701, Korea

Received April 27, 2012 /Revised July 21, 2012 / Accepted July 27, 2012

\begin{abstract}
Synovium is the soft tissue that lines the non-cartilaginous surfaces within joints. It has been reported that synovial cells are activated during the pathogenesis of rheumatoid arthritis. In this study, we quantitate and compare the cellular composition of synovia derived from individuals with non-inflammatory osteoarthritis (OA) and those with inflammatory rheumatoid arthritis (RA). Synovia from OA $(n=8)$ and RA $(n=5)$ patients were used for hematoxylin and eosin (H\&E) staining. A light microscopic examination has shown that RA synovia were morphologically thickened and hypertrophied as compared to OA synovia. We also performed an immunohistochemistry (IHC) analysis to classify cell types in the synovia using CD68, CD90, or PGP9.5 markers. As a result, we obtained quantitative data regarding the cell populations, which are macrophages in the lining layer and FLSs in the subintimal layer of the synovium. Further Photoshop analyses of the H\&E images could allow the counting of the number and layer of the cells in the synovium. The number and layers of the macrophage cells were increased in the lining layer of the RA synovia as compared to the OA synovia. FLS cells also were increased in the subintimal layer of RA synovia. Therefore, quantification of the H\&E stained images via Photoshop is a possible analysis protocol for synovium study. This quantitation also supports the idea that the increases in cell number and cell activation are important processes for RA pathogenesis.
\end{abstract}

Key words : Synovium, arthritis, hematoxylin and eosin (H\&E) staining, immunohistochemistry (IHC), photoshop

\section{서 론}

관절염은 관절 주변의 연골 또는 활막 조직의 이상으로 발 병하는 질환으로, 무리한 신체적 사용, 노화, 비만 등으로 인한 연골의 마모에 의해 발병하는 골관절염은 비염증성 질환인 반면, 염증성 질환인 류마티스 관절염은 활막 내 면역세포들 의 비정상적인 증식으로 인하여 염증이 발생하고 판누스를 형성하며, 결과적으로 인대, 연골 및 뼈까지 손상을 일으키는 질병이다[1,4]. 류마티스 관절염은 여러 부위 관절에서 동시에 발생할 수 있으며, 유전적인 요인과 감염, 그리고 호르몬 이상 등이 원인이며, 젊은 연령대에서도 발병할 수 있다.

비연골성의 얇은 세포층으로 구성된 활막 조직에는 림프 구, 대식세포, 섬유아세포 등의 다양한 세포들이 존재한다고 알려져 있으며, 염증성 질환인 류마티스 관절염은 이러한 활 막 조직내 세포들의 이상으로 발병할 수 있다고 알려져 왔다 [9]. 활막 조직의 내막층(intimal lining layer)에는 대식세포 들이 분포하며, 내막하층(subintimal layer)에는 대식세포 (macrophage)와 섬유아세포 유사 활막세포(fibroblast like synoviocyte: FLS)가 분포하고 있다[5]. 두 세포군은 형태학 적 및 생물학적 기능에 분명한 차이를 보인다. 대식 세포는

*Corresponding author

Tel : +82-33-250-8532, Fax : +82-33-251-3990

E-mail : kckim@kangwon.ac.kr
관절강 내의 불필요한 물질들을 제거하는 역할을 수행할 뿐 아니라 항원을 제시함으로서 면역반응에 관여한다. FLS는 류마티스 관절염환자의 활막내 만성 염증을 유지하고 병의 증상을 악화시키는 역할을 한다[5,9]. 즉, 류마티스 관절염 발 병과정에서 IL-1은 FLS를 자극하고, IL-6, IL-8과 같은 염증성 사이토카인의 분비를 촉진하며 부착인자의 발현을 증가시켜 염증반응을 유도한다[10]. 또한 VEGF의 생성을 자극하여 혈 관형성을 유도함으로서 활막세포의 증식을 활성화시키며 $\mathrm{MMP}$ 와 같은 효소를 분비시켜 연골 및 뼈의 파괴를 촉진한 다고 보고된바 있다[7]. 따라서 류마티스 관절염과 같은 염증 성 질환에서 활막 세포의 동정 및 연구는 병리기전을 이해하 는데 중요한 의미가 있을 것이다.

인체유래 활막조직을 이용한 세포의 정량적인 분석은 주로 마커단백질을 이용한 면역조직화학염색(immunohistochemistry: $\mathrm{IHC}$ ) 분석을 통해 다양한 질환의 활막조직에서 시도되 었다[3,14,15]. 2004년 Singh 등은 정상 활막조직에는 T 세포와 대식세포 등이 분포하고 있지만, $\mathrm{B}$ 세포는 관찰되지 않는 것이 특징적이다라고 보고하였으며, 관절염의 발병과정에서 $\mathrm{B}$ 세 포의 역할이 중요할 수 있을 것이라고 제시하였다. 정형성 관 절염(orthopaedic arthropathies)의 경우에는 세포의 분포가 정상 활막 조직과 골관절염 활막 조직의 중간단계의 병리학적 소견이 나타난다고 보고되었다. 또한 골관절염과 류마티스 관 절염 활막 조직에 사이토카인 $\mathrm{IHC}$ 를 수행한 후 사이토카인의 
분비능 차이를 비교 분석 한 연구에서 혈관형성과 관련된 많 은 사이토카인의 분비가 활발하게 진행된 것을 보고하기도 하였다. 이러한 연구에도 불구하고 활막 조직의 세포에 대한 동정 및 정량분석에 대한 다양하고 체계적인 자료 제시는 여 전히 중요한 의미가 있을 것이다.

본 연구는 관절염 환자의 수술시 채취된 활막 조직이 특별 히 정형화된 형태를 갖고 있지 않고 겔 상태와 같은 구조를 하고 있기 때문에 H\&E 염색 후 광학현미경을 통해 관찰된 이미지를 분석하는 과정에서 발생할 수 있는 데이터 분석의 문제점을 정량적으로 해결하고자 하였다. 활막 조직의 내막층 과 내막하층에 비교적 일정한 수의 대식세포와 FLS 가 상주하 기 때문에 H\&E 염색후 얻어진 이미지를 포토샵를 이용하여 분석 가능한 형태의 이미지로 전환한 다음, 세포 계수 등을 수행함으로써 비염증성 질환인 골관절염과 염증성 관절염인 류마티스 관절염의 활막조직의 차이를 비교 분석해 보고자 하였다. 또한 대식세포와 FLS 마커들을 이용한 IHC 결과와 비교함으로써 세포 동정을 수행하여 활막조직내의 세포 분포 에 대해 유추할 수 있었다.

\section{재료 및 방법}

\section{대상}

2010년 9월부터 2011년 3월까지 한양대학교에서 수술이 행 해진 골관절염, 류마티스 관절염 환자들의 활막 조직을 채취 하여 본 연구에 사용하였다. 환자의 동의와 한양대학교 및 병 원 윤리위원회의 심의를 거쳐 실험이 진행되었으며, 채취한 활막 조직은 $10 \%$ 중성 포르말린으로 고정시킨 후 블록제작에 이용되었다. 본 연구는 골관절염 환자 8 명과 류마티스 관절염 환자 5 명의 활막조직을 사용하였다.

\section{H\&E 염색}

포르말린으로 고정한 활막 조직을 흐르는 물에 충분히 수세 한 후 저농도에서 고농도의 에탄올로 탈수시킨다. 자일렌으로 투명화 과정을 거친 후 파라핀으로 포매하고 조직 절편기를 이용하여 $4 \mu \mathrm{m}$ 두께로 절편을 제작하였다. 이를 슬라이드에 부착한 후 자일렌과 에탄올을 이용하여 파라핀을 제거하였다. Hematoxylin으로 핵염색을 한 후 증류수 등을 이용하여 수세 하였으며, eosin을 이용하여 세포질을 염색하였다. 이후 슬라 이드를 봉입(mounting) 하여 광학현미경을 이용하여 $400 \mathrm{X}$ 배 율에서 관찰하였다.

\section{면역조직화학염색(immunohistochemistry: $\mid \mathrm{HC})$}

CD68 (Abcam, USA), CD90 (Abcam, USA), PGP9.5 (Millipore, USA)의 마커에 대한 IHC는 UltraVision LP Large Volumn Detection System HRP Polymer 키트를 이용하였다 (Thermo scientific, USA). 절편 슬라이드를 자일렌으로 탈파
라핀화 한 후 고농도에서 저농도 알코올 처리 과정을 통하여 활막조직을 수화시켰다. pH 6.0 citrate buffer에서 고온고압 과정을 통하여 항원노출(antigen retrieval)을 하였으며, 활막 조직내 존재하는 과산화효소 활성을 억제하기 위하여 $3 \%$ $\mathrm{H}_{2} \mathrm{O}_{2} /$ methanol에 처리 하였다. 비특이적인 결합을 방지하기 위하여 ultra $\mathrm{V}$ block reagent로 5 분간 반응시켰으며 $\mathrm{CD} 68$ (1:50), CD90 (1:100), PGP9.5 (1:100) 항체를 희석하여 상온에 서 1 시간 30 분동안 처리하였다. TBS-T 버퍼로 3 희 충분하게 수세한 후 1 차 항체 enhancer로 반응시켜 항원과 항체의 반응 을 극대화 시켰다. HRP polymer (Thermo scientific, USA)로 2차 항체 반응의 효율성을 높였으며 DAB chromogenic substrate를 이용하여 발색 반응을 유도하였다.

\section{활막조직 내 세포 및 활막층의 정량 분석}

$\mathrm{H \& E}$ 염색 후 광학현미경 관찰을 통하여 여러 군데의 이미 지를 얻었다. 저장된 사진파일은 세포 수 측정 등을 위해서 포토샵의 흑백 반전 기능을 이용하였다. 흑백이미지에서 나타 난 검은점 하나 하나는 세포로 간주하고, 활막 내막층과 활막 하층으로 나누어 세포의 수와 층을 계수하였다. 활막 내막층 의 경우 분포하는 세포를 모두 계수하였으며 세포층의 분석은 서로 엇갈린 배열을 하고 있는 세포들을 하나의 층으로 간주 하였다. 내막하층의 경우에는 이미지에서 보여지는 화면에 일 정 단위 면적을 정한 뒤 5 군데를 임의로 선정하여 계수하였다. 혈관의 수는 $\mathrm{H \& E}$ 이미지를 바탕으로 이미지내에 존재하는 혈관의 수를 계수하여 분석하였다.

\section{통계 유의성 검증}

복수의 실험자에 의한 블라인드 테스트로 세포 계수 등을 반복한 후 Graphpad prism5 프로그램을 이용하여 평균, 표준 편차를 얻었으며 통계적 유의성을 위해 t-test를 시행하였다.

\section{결 과}

\section{활막 조직 정보}

본 연구진은 골관절염 활막조직 8 개와 류마티스 관절염 활 막조직 5 개를 대상으로 $\mathrm{H \& E}$ 염색 등을 시행하였다.. 골관절염 활막조직은 남성 1 명과 여성 7 명으로부터 얻어졌다. 평균연령 은 54세부터 79세까지 75.3세였다. 반면 류마티스 관절염 활막 조직은 모두 여성 환자로부터 채취되었으며, 43세부터 64세까 지 평균연령은 54.8 세로 다양한 분포를 보였다. 류마티스 관절 염 환자들의 경우에는 methotrexate, TNF-a antagonist, steroid 병합 치료를 받은 환자 1명, hydroxychloroquine, tacrolimus 치료를 받은 환자 1명, methotrexate, tacrolimus, steroid 치료를 받은 환자 1 명의 경우와 DMARDs 투여가 없는 환자 2 명의 활막조직이 사용되었다. 


\section{골관절염과 류마티스 관절염 활막조직의 형태학적 비교 분석} 골관절염과 류마티스 관절염의 활막조직을 $\mathrm{H \& E}$ 염색한 결 과, 골관절염 활막조직은 얇은층의 활막 내막층으로 구성되어 있는 것을 확인하였으며, 또한 내막하층에 분포하고 있는 혈 관들이 활막내막층과 비교적 가까이 분포되어 있는 것을 확인 할 수 있었다(Fig. 1A,B). 또한 내막하층에는 비교적 많은 교질 이 분포하고 있었으며, 내막하층에 존재하는 세포들은 많아 보이지 않음을 알 수 있었다. 그러나 류마티스 관절염의 활막 조직은 활막내막층의 세포들의 수가 현저하게 늘어나 있었으 며, 또한 내막층의 두께도 다소 두꺼워진 양상을 확인할 수 있었다(Fig. 1C,D). 또한 류마티스 활막조직의 내막하층은 전 반적으로 비대해진 형태를 보였으며, 하층의 비대로 인하여 혈관의 구조가 좁아진 특징을 관찰할 수 있었다. 이러한 결과 는 골관절염에 비하여 류마티스 관절염의 활막조직에서 더 많은 형태적인 변화가 발생할 뿐 아니라, 조직내에 존재하는 다양한 세포들의 활성화를 통한 세포수 증가 및 세포의 이동 이 발생하였기 때문에 세포의 수적인 변화도 수반되었을 것으 로 사료된다.

\section{마커 $\mathrm{IHC}$ 분석을 통한 활막세포의 동정}

활막조직의 내막층과 내막하층에는 다양한 종류의 세포들 이 분포되어 있다. 따라서 활막 세포 마커인 CD68, CD90, PGP9.5 등을 이용하여 내막층과 내막하층의 세포를 동정하 고 분포를 비교 분석하였다. Fig. 2는 류마티스 관절염 활막 조직 중 하나를 다양한 마커를 이용하여 IHC 분석한 대표적
인 결과이다. 대식세포의 마커인 CD68을 이용하였을 때 골 관절염과 류마티스 관절염의 활막 내막층 부위가 염색되는 것으로 보아 대식세포들이 내막층에 집중적으로 분포하는 것을 확인할 수 있었다. 또한 내막하층에서도 CD68 세포가 관찰되는 것으로 보아 이 부위에서도 대식세포가 분포하는 것으로 추정할 수 있다. 두 질환 모델을 비교하였을 때 골관 절염 활막조직에 비하여 류마티스 관절염 활막조직의 내막 층에서 $\mathrm{CD} 68$ 세포의 분포는 수적으로 훨씬 더 많았고, 더 두 꺼운 양상을 보였다. 한편 FLS 마커인 CD90 세포는 내막층 에서는 거의 보이지 않았던 반면, 내막하층에서 많이 분포하 고 있는 것으로 확인 되었으며, 골관절염 활막조직에 비하여 류마티스 관절염 활막조직에서 더 많은 CD90 세포를 확인할 수 있었다. 한편 PGP9.5는 대식세포와 FLS 등을 모두 검출할 수 있는 마커로서 $\mathrm{CD} 68$ 과 $\mathrm{CD} 90$ 의 마커들을 동정 분류하는 데 보완적인 마커로서 사용되어졌다. 그러므로 마커 IHC 분 석은 활막조직의 내막층, 내막하층의 세포들을 동정하는데 용이하게 사용되어질 수 있다.

\section{활막 내막층의 세포 정량을 위한 포토샵 분석}

H\&E 염색을 통하여 활막 내막층의 세포와 내막층 수의 차 이가 보여졌기 때문에 세포 및 층의 계수를 분석하였다. 세포 를 효과적으로 계수하기 위한 방법으로 광학 현미경 관찰을 통해 얻어진 활막조직 이미지를 포토샵 반전 기능을 이용하여 흑백의 이미지로 전환 하였다(Fig. $3 \mathrm{~A}$ ). H\&E 염색이미지와 비교한 결과 반전된 이미지의 내막층을 따라 배열되는 일정한

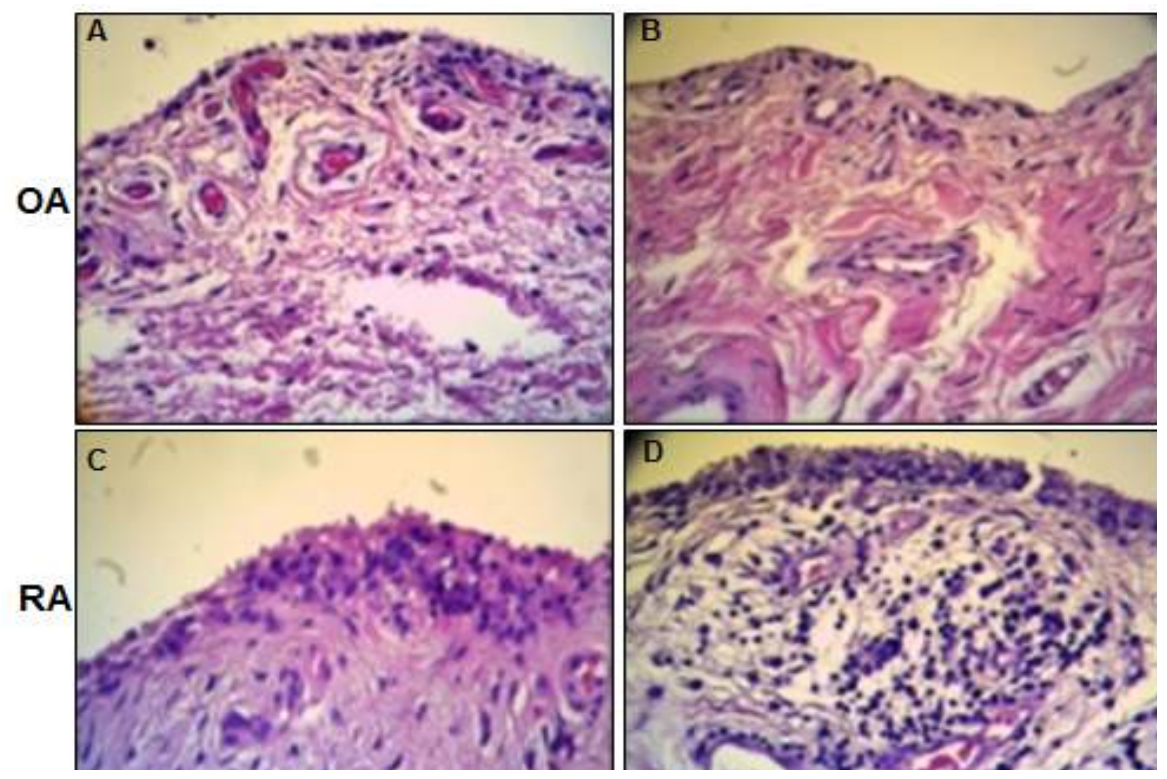

Fig. 1. Typical images of H\&E staining on synovium from OA or RA patients. Synovial tissues were collected, cut in $4 \mu \mathrm{m}$ slices and followed by H\&E staining. These images were magnified by 400 fold with light microscope. Upper images (A, B) are H\&E images from OA (osteoarthritis). In contrast, lower images (C, D) are H\&E images from RA (rheumatoid arthritis). Lining layer and subintimal layer of synovium can be easily classified in these images. Thickness of synovial lining cells and cell infiltration are shown in RA. 

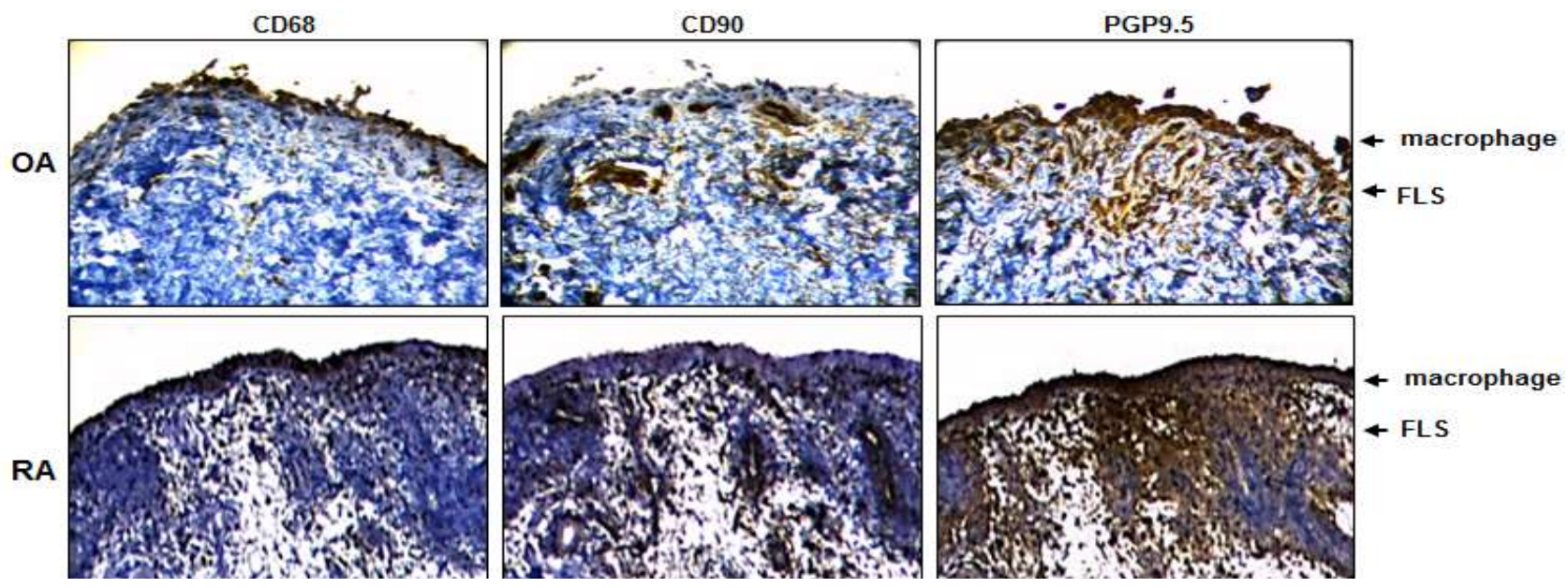

Fig. 2. Typical images of IHC using various markers such as CD68, CD90, and PGP9.5. Synovial tissues were collected, cut in $4 \mu \mathrm{m}$ slices and followed by IHC staining. CD68 (1:50) marker was used for synovial macrophage, and CD90 (1:100) was for FLS (fibroblast like synoviocyte), and PGP9.5 (1:100) was for the both.
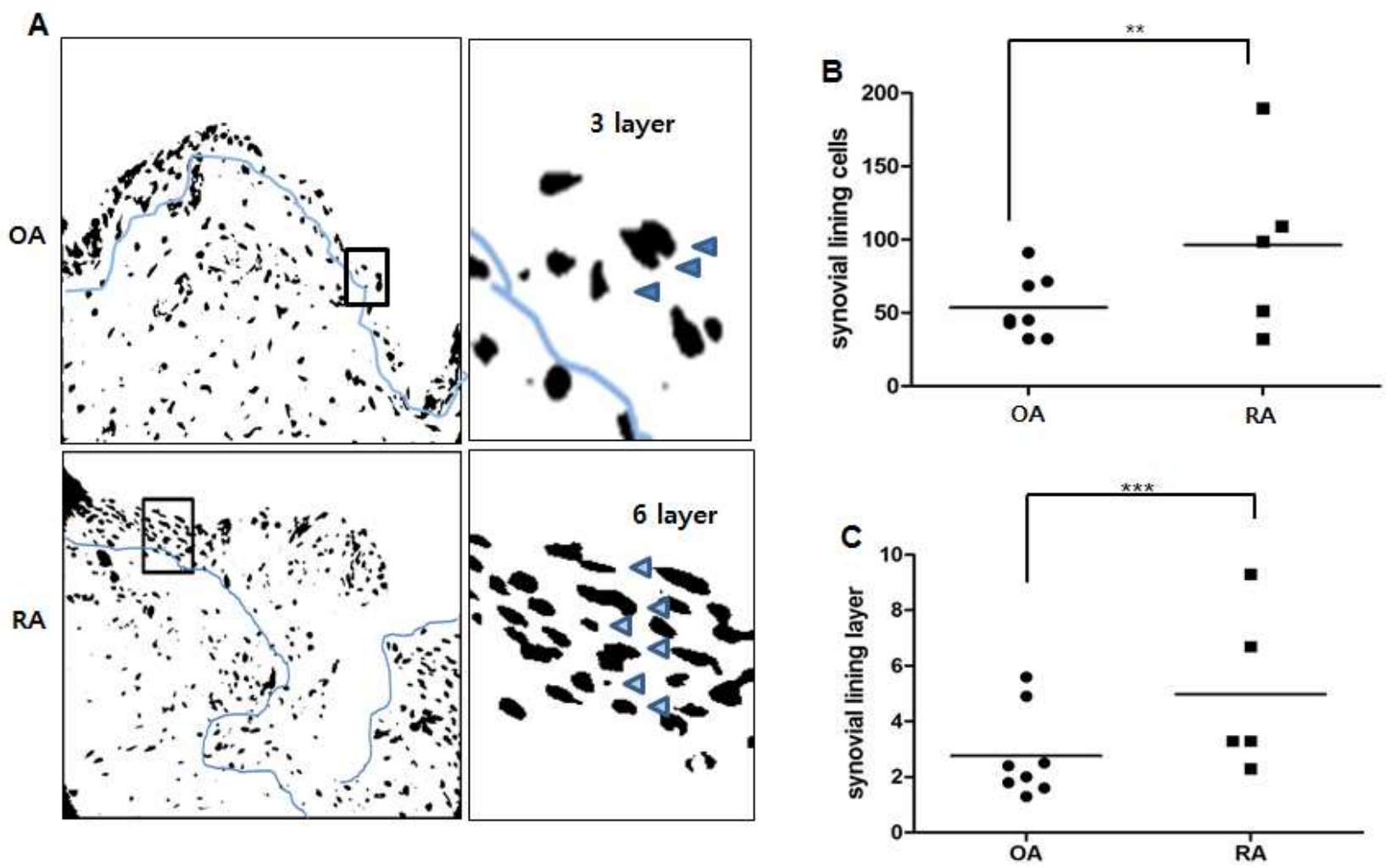

Fig. 3. Photoshop analyses on number and layer of synovial lining cells. A) Microscopic images were reanalyzed by color brightness in photoshop. Afterthat, several investigators counted cell number of lining layer in blinded manner on tissues. B) The data was expressed as mean S.D. for the number of cell or layer. ${ }^{* *} ; p<0.05,{ }^{* * *} ; p<0.01$

크기 이상의 검은 점 하나하나는 세포를 의미한다는 사실을 알 수 있었다. 따라서 400배 관찰로 얻어진 H\&E 염색 이미지 의 세포 수를 계수 할 수 있었고, 연구자의 편견을 없애기 위하 여 같은 조직의 다양한 부위에서 얻어진 이미지를 대상으로 복수의 계수자들의 블라인드 테스트로 정량된 결과를 도출하
였다. 그 결과, 류마티스 관절염 활막조직의 내막층에 존재하 는 대식세포는 평균 96개인 반면, 골관절염 활막조직의 내막 층에는 53개의 대식세포가 존재하는 것을 알 수 있었으며, 류 마티스 관절염 활막조직에서 약 1.5 배 높게 나타났다(Fig. 3B). 또한 내막층의 수에 대한 계수도 시도하였다. 골관절염 활막 
A

$O A$

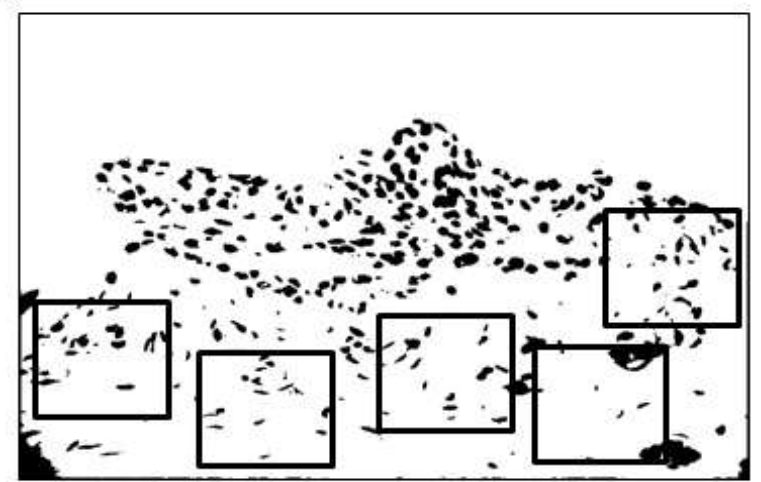

RA

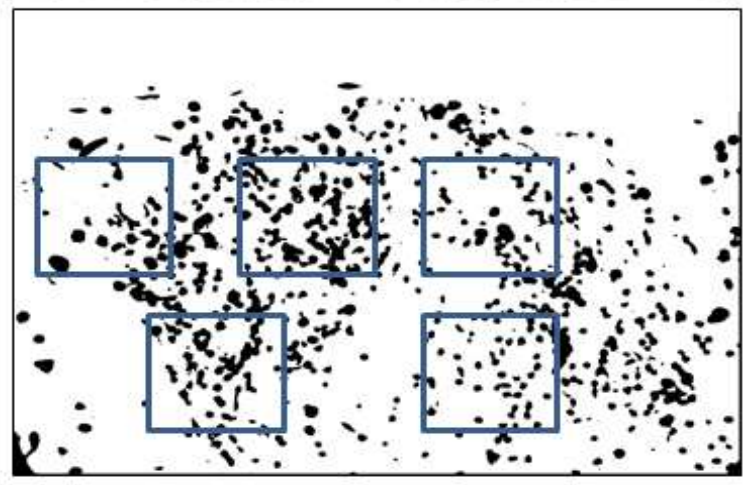

B

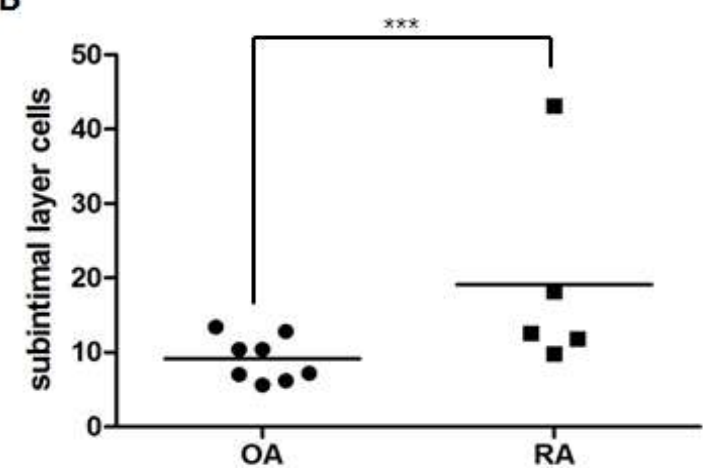

C

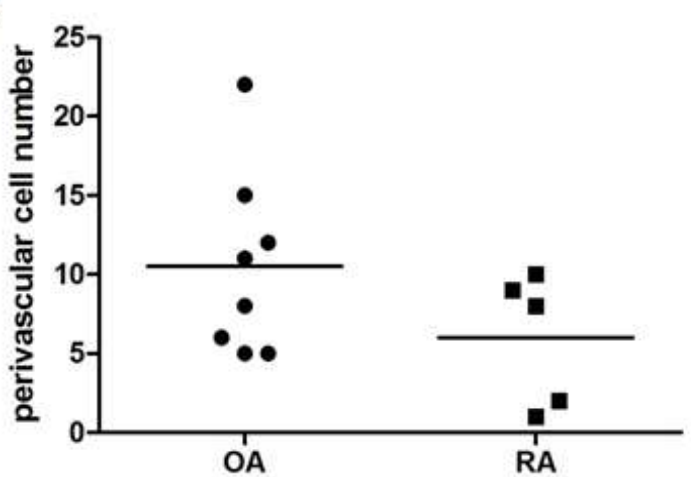

Fig. 4. Photoshop analyses on number of synovial subintimal layer cells and perivascular structure. A) Microscopic images were reanalyzed by color brightness in photoshop. Afterthat, several investigators counted cell number of subintimal layer in blinded manner on tissues. B) Perivascular number was counted from images of H\&E staining. The data was expressed as mean S.D. for the number of cell or layer. ${ }^{* * *} ; p<0.01$

조직의 층은 평균 2.3 층으로 이루어져 있었으나, 류마티스 관절염 활막조직은 4.4 층으로 두배정도 더 두꺼운 층이 형성 되어지고 있음을 알 수 있었다(Fig. 3C). 그러므로 염증성 질환 인 류마티스 관절염은 발병과정에서 대식 세포의 활성화 또는 수적증가에 따른 내막층의 비대가 발생할 수 있다고 추측할 수 있다.

\section{내막하층 세포 및 혈관수 분석}

활막조직의 내막층은 골관절염, 류마티스관절염 모두에서 대식세포들로 이루어진 층의 형태로 나타났지만, 내막하층의 경우에는 많은 기질들로 인해 다양한 형태적인 특징과 세포분 포에서 차이가 발생했기 때문에 포토샵 분석으로 내막하층의 세포수 등을 측정하였다. 일정한 단위면적을 정한후 5 군데의 무작위 지역을 계수 함으로써 내막하층의 세포수를 결정하였 다(Fig. 4A). 골관절염 활막조직의 내막하층에서는 단위면적 당 평균 9개의 세포가 관찰되었지만, 류마티스 관절염 활막조 직의 내막하층은 평균 19 개의 세포가 관찰되었다(Fig. 4B). 이 러한 현상은 류마티스 관절염 발병과정에서 염증반응과 관련 된 FLS세포들의 침윤현상이 일어나기 때문에 세포의 수가 현 저하게 증가한 것으로 보여진다. 한편 활막조직의 내막하층에
는 많은 혈관들이 분포하고 있다. 류마티스 관절염은 내막하 층의 비대화가 일어난다고 알려졌는데, 이러한 현상으로 인하 여 류마티스 활막조직의 내막하층에 존재하는 혈관의 수는 골관절염과 비교하였을 때 약 2 배 가량 줄어든 것을 확인하였 다(Fig. 4C). 또한 류마티스 관절염의 경우 활막의 비후가 심하 기 때문에 혈관의 위치가 내막층으로부터 상대적으로 멀리 위치하고 있음을 알 수 있었다. 그러므로 류마티스 관절염 발 병과정에서 FLS세포들과 같은 다양한 세포들이 내막하층에서 활성화되기 때문에 골관절염 활막조직에 비하여 류마티스 관 절염 활막조직이 더욱더 비대해지는 현상이 발생, 내막하층내 의 혈관조직은 퇴화되는 과정이 발생하는 것으로 추정할 수 있다.

\section{고 찰}

만성 염증 질환인 류마티스 관절염은 관절부위의 많은 종류 세포들의 활성화를 통하여 발병이 시작된다. 초기 면역반응에 서는 T 세포의 활성화로 아형인 Th17세포에서 IL-6와 IL-1B와 같은 사이토카인을 분비하고, 발병이 진행되면 IL-17 분비를 증가시킨다고 보고되고 있다[11,13]. 그러나 류마티스 관절염 
이 악화되면 활막조직에 상주하는 활막세포의 활성화를 통하 여 연골파괴 분해효소가 분비됨으로써 관절의 파괴가 나타난 다[6]. 그러나 골관절염의 경우 비염증성 질환이기 때문에 이 러한 연쇄적인 형태의 세포 활성화는 발생하지 않는다고 알려 져 있다[12]. 따라서 세포의 활성화 측면에서 살펴보면 골관절 염과 류마티스 관절염의 병리기전은 분명히 다른 과정으로 진행된다 $[5,9]$. 활막조직내의 내막층에 존재하는 대식세포와 내막하층에 존재하는 FLS 세포는 염증반응에 관련된 사이토 카인 분비를 조절할 뿐 아니라 연골 파괴를 일으키는 인자들 을 조절한다. 그러므로 활막조직은 염증성 관절 질환에 있어 서 중요한 역할을 할 것으로 사료되며, 활막조직에 분포하는 세포들의 역할에 대한 많은 연구들이 진행되고 있다. 그러나 수술로 채취한 활막조직 자체가 정형화된 형태를 갖고 있지 않은 겔과 같은 구조로 이루어졌기 때문에 정량화된 결과를 분석하기에는 다소 어려움이 있고, 질환의 활성도가 불균등한 환자들을 대상으로 검체가 얻어져 활막조직의 형태적인 다양 성이 관찰되어 연구의 어려움이 있는 것이 현실이다.

따라서 본 연구에서는 활막조직의 형태적인 특징을 이해하 고, 활막조직내의 세포들의 수적인 변화를 정량화하는 분석을 시도하였다. H\&E 염색을 통해 살펴보면 골관절염의 활막조직 과 비교하여 류마티스 관절염의 활막조직은 활막의 비후화 현상, 세포수의 증가와 같은 두드러진 차이를 볼 수 있다. 이러 한 관찰을 바탕으로 H\&E 염색을 통해 얻어진 이미지를 포토 샵으로 변환하여 정확하고 명료한 정량적인 분석을 수행하였 다. 포토샵의 반전기능으로 이미지를 변경하였더니 세포는 일 정한 크기이상의 검은점으로 나타났으며, 세포수와 내막층의 수를 쉽게 계수 할 수 있었다. 또한 실험자의 편견을 없애기 위해 다수의 골관절염 활막조직, 류마티스 관절염 활막조직의 이미지를 모두 혼합한 후 여러명의 실험자들에게 계수를 의뢰 하였다. 이러한 단순 계수방식은 $\mathrm{H \& E}$ 염색으로부터 얻어진 이미지를 보고 분석하는 방법에 비해 훨씬 단순화된 방법으로 세포성과 비세포성 성분에 대한 판단을 용이하게 할 수 있는 장점이 있다. 활막 내막층의 세포와 내막층수의 차이를 정량 화 한 결과, 류마티스 관절염의 활막조직 내막층의 세포가 골 관절염 활막조직에 비해 다소 증가하였다는 정량적인 결과를 얻을 수 있었다. 한편 내막층의 두께도 류마티스관절염에서 약 2 배 정도의 더 두꺼운 세포층으로 구성 되어져 있다는 정량 적인 결과를 확인할 수 있었다. 활막조직의 내막하층에는 류 마티스 관절염 발병에서 기능과 중요성이 증대되고 있는 FLS 세포가 분포하고 있는 부위로서 종양세포의 특징을 보이기도 한다[2]. 류마티스 관절염에서 FLS세포는 p53 유전자의 돌연 변이가 발생할 수 있기 때문에 세포의 이상증식, 세포 형질전 환등이 진행되며, 내막하층에서의 세포 침윤 등이 발생할수 있다[2,9]. 내막하층에 대한 포토샵을 이용하여 FLS세포 정량 분석을 수행한 결과 내막하층에서도 세포의 수적인 증가가 나타났기 때문에, FLS세포의 활성화와 관련된 현상으로 판단
된다. 류마티스 발병과정에서 혈관은 $\mathrm{VEGF}$ 의 혈관신생과 관 련된 인자들이 분비되기 때문에 혈관의 수는 증가 할 것으로 추측되어 왔다[7]. 두 질환의 $\mathrm{H \& E}$ 염색 이미지를 이용하여 같은 배율내에서 혈관의 수를 계수한 결과 오히려 혈관의 수 는 감소된 현상으로 나타났다. 류마티스 관절염의 진행에서 활막조직의 비후화 및 기능이상으로 혈관도 함께 퇴화하기 때문일 것으로 추측되지만, 이러한 차이에 대한 더 많은 연구 가 필요할 것이다.

골관절염과 류마티스 관절염의 병리기전을 이해하기 위해 활막조직에 대한 많은 연구들이 필요하다. 현재 다양한 마커 들이 활막조직 내의 세포들을 동정하는데 사용되어지고 있다 $[8,16]$. 본연구에 의하면 대식세포의 마커인 CD68을 이용하여 $\mathrm{IHC}$ 를 수행하면 활막조직내에서 증가된 대식 세포들에 대한 동정이 용이한 것으로 판단된다. 따라서 활막 내막층에 분포 하는 $\mathrm{CD} 68$ 대식세포들은 다양한 일차 염증반응을 매개하기 때문에 골관절염보다 류마티스 관절염에서 활발한 염증반응 에 관여할 것으로 추정할 수 있다. 한편 FLS세포의 마커인 $\mathrm{CD} 90$ 은 내막하층에서 주로 검출되었는데, 따라서 류마티스 관절염에서 FLS 세포의 수적증가는 연골의 파괴 등에 관여할 것으로 보여진다.

한편, 관절 질환을 연구하기 위해서는 활막조직에 대한 체 계적인 연구가 필요하다. 정상인의 활막 조직을 구하기는 어 려움이 있기 때문에 골관절염과 류마티스 관절염의 활막조직 이 많이 사용되어진다. 또한 컴퓨터 프로그램의 개발과 정확 도가 증가되고 있기 때문에 이를 이용한 다양한 분석 방법들 이 개발될 수 있다. 본연구에서 제시된 활막조직의 H\&E 염색 후 포토샵 분석은 류마티스 관절염의 발병기전과정에서 세포 들의 활성화가 진행된다는 사실을 뒷받침할 수 있는 분석 방 법이다. 류마티스의 활막조직에서 대식세포, FLS등의 세포들 이 활성화되어 이상증식이 일어나고 있다는 정량적인 분석은 향후 활막조직을 통한 염증성 관절염의 발병을 조절하고 제어 하는 대상으로 중요한 역할이 있을 것이라 사료된다.

\section{감사의 글}

본 연구 수행을 위해 사람 관절염 시료를 제공해 주신 한양 대학교 류마티스 내과 김태환 교수께 감사드리며, 본 연구는 연구재단 일반연구자지원사업(지역대학 우수과학자: 20110006047)으로 수행하였음. 제1저자는 연구재단 이공계 국가장 학생 fellowship (S2-2009-000-00756-1) 지원을 받았음.

\section{References}

1. Abramson, S. B. and Attur, M. 2009. Developments in the scientific understanding of osteoarthritis. Arthritis Res. Ther. 11, 227.

2. D'Arcy, P., Ryan, B. A. and Brodin, B. 2009. Reactivation 
of p53 function in synovial sarcoma cells by inhibition of p53-HDM2 interaction. Cancer Lett. 275, 285-292.

3. Farahat, M. N., Yanni, G., Poston, R. and Panayi, G. S. 1993. Cytokine expression in synovial membranes of patients with rheumatoid arthritis and osteoarthritis. Ann. Rheum Dis. 52, 870-875.

4. Fearon, U., Griosios, K., Fraser, A., Reece, R., Emery, P., Jones, P. F. and Veale, D. J. 2003. Angiopoietins, growth factors, and vascular morphology in early arthritis. $J$. Rheumatol. 30, 260-268.

5. Fox, D. A., Gizinski, A., Morgan, R. and Lundy, S. K. 2010. Cell-cell interactions in rheumatoid arthritis synovium. Rheum Dis. Clin. North Am 36, 311-323.

6. Gruber, H. E., Ingram, J. A., Hoelscher, G. L., Zinchenko, N., Norton, H. J. and Hanley, E. N. Jr. 2009. Matrix metalloproteinase 28, a novel matrix metalloproteinase, is constitutively expressed in human intervertebral disc tissue and is present in matrix of more degenerated discs. Arthritis Res. Ther. 11, R184.

7. Kim, W. U., Kang, S. S., Yoo, S. A., Hong, K. H., Bae, D. G., Lee, M. S., Hong, S. W., Chae, C. B. and Cho, C. S. 2006. Interaction of Vascular Endothelial Growth Factor 165 with Neuropilin-1 Protects Rheumatoid Synoviocytes from Apoptotic Death by Regulating Bcl-2 Expression and Bax Translocation. J. Immunol. 177, 5727-5735.

8. Kunisch, E., Fuhrmann, R., Roth, A., Winter, R., Lungershausen, W. and Kinne, R. W. 2004. Macrophage specificity of three anti-CD68 monoclonal antibodies (KP1, EBM11, and PGM1) widely used for immunohistochemistry and flow cytometry. Ann. Rheum Dis. 63, 774-784.

9. Lee, S. H. 2005. Role of synovial fibroblasts in rheumatoid arthritis. Hanyang Medical Reviews 25, 36-42.

10. Liu, H., Perlman, H., Hoffmann, A., Thimmapaya, B. and Richard, M. P. 2000. Regulation of IL-6 and IL-8 expression in rheumatoid arthritis synovial fibroblasts: the dominant role for NF-kB but not C/EBPb or c-Jun. J. Immunol. 165, 7199-7206.

11. Lundy, S. K., Sarkar, S., Tesmer, L. A. and Fox, D. A. 2007. Cells of the synovium in rheumatoid arthritis. $\mathrm{T}$ slynphocytes. Arthritis Res. Ther. 9, 202.

12. Myers, S. L., Flusser, D., Brandt, K. D. and Heck, D. A. 1992. Prevalence of cartilage shards in synovium and their association with synovitis in patients with early and endstage osteoarthritis. J. Rheumatol. 19, 1247-1251.

13. Nakano, K., Yamaoka, K., Hanami, K., Saito, K., Sasaguri, Y., Yanagihara, N., Tanaka, S., Katsuki, I., Matsushita, S. and Tanaka, Y. 2011. Dopamine induces IL-6-dependent IL-17 production via D1-like receptor on CD4 naive T cells and D1-like receptor antagonist SCH-23390 inhibits cartilage destruction in a human rheumatoid arthritis/SCID mouse chimera model. J. Immunol. 186, 3745-3752.

14. Pessler, F., Dai, L., Diaz-Torne, C., Gomez-Vaquero, C., Paessler, M. E., Zheng, D. H., Einhorn, E., Range, U., Scanzello, C. and Schumacher, H. R. 2008. The synovitis of "on-inflammatory" orthopaedic arthropathies: a quantitative histological and immunohistochemical analysis. Ann. Rheum Dis. 67, 1184-1187.

15. Singh, J., Arayssi, T., Duray, P. and Schumacher, H. 2004. Immunohistochemistry of normal human knee synovium: a quantitative study. Ann. Rheum Dis. 63, 785-790.

16. Smith, J. B. and Haynes, M. K. 2002. Rheumatoid arthritismolecular understanding. Ann. Intern. Med 136, 908-912.

\section{초록 : H\&E 염색 이미지의 포토샵 분석을 이용한 골관절염과 류마티스 관절염 활막 세포의 정량 분석 박진아 · 김근철* \\ (강원대학교 자연과학대학 생명과학과)}

활막조직은 관절부위에 존재하는 비연골성의 얇은 세포층으로 구성되어 있으며, 류마티스 관절염 등에서 활성 화 되어진다. 우리는 골관절염 $(\mathrm{n}=8)$ 과 류마티스 관절염 $(\mathrm{n}=5)$ 에서 유래한 활막조직을 대상으로 활막조직내의 세포 를 정량화하고 세포성분들을 비교 분석하고자 하였다. 활막조직을 $\mathrm{H \& E}$ 염색한 후 광학현미경으로 관찰하였을 때 류마티스 관절염의 활막조직은 골관절염에 비해 형태적으로 두터워졌으며 비후된 양상이었다. 또한 CD68, CD90, PGP9.5 등과 마커들을 이용하여 IHC 분석을 수행한 결과 활막조직의 내막층과 내막하층에 존재하는 세포 들을 특성을 분한 결과 내막층에는 대식세포가 집중적으로 분포하며, 내막하층에는 대식세포와 섬유아세포 유사 활막세포(FLS)가 존재한다는 사실을 알 수 있었다. H\&E 이미지를 포토샵 프로그램을 이용하여 반전시켜 내막층 과 내막하층 부위별로 세포계수 및 세포층계수를 수행하였다. 내막층 분석 결과 류마티스 관절염의 활막조직의 골괄절염보다 대식세포의 수와 층이 현저하게 증가된 것을 확인할수 있었다. 또한 류마티스 관절염의 활막조직 의 내막하층분석결과 섬유아세포 유사 활막세포의 수적인 증가를 계수 할수 있었다. 또한 류마티스 관절염의 경 우 활막의 비후가 심하기 때문에 혈관의 위치가 내막층으로부터 상대적으로 멀리 위치하고 있음을 알 수 있었다. 그러므로 $\mathrm{H \& E}$ 염색 이미지의 포토샵 분석을 이용한 골관절염과 류마티스 관절염 활막조직에 대한 정량 분석 방법은 류마티스 관절염의 발병과정에서 세포들이 활성화된다는 사실을 증명하는데 유용할 것으로 사료된다. 